\title{
Chemical Composition of the Marc of a Wild Tropical Plant Tacca involucrata (Schumach and Thonn, 1827)
}

\author{
Joel Aondohulugh Bosha1 ${ }^{*}$, Aruh Ottoh Anaga ${ }^{2}$, Isaac Uzoma Asuzu² \\ ${ }^{1}$ Department of Veterinary Physiology and Pharmacology, University of Agriculture, Makurdi, Nigeria \\ ${ }^{2}$ Department of Veterinary Physiology and Pharmacology, University of Nigeria, Nsukka, Nigeria \\ Email: ${ }^{\text {boshajoel@yahoo.com }}$
}

Received 29 December 2014; accepted 10 January 2015; published 13 January 2015

Copyright (C) 2015 by authors and Scientific Research Publishing Inc.

This work is licensed under the Creative Commons Attribution International License (CC BY). http://creativecommons.org/licenses/by/4.0/

CC) (i) Open Access

\section{Abstract}

Tacca involucrata (Batflower or Polynesian arrowroot) tubers are a stable food in tropics where it occurs. In central Nigeria, it is processed locally after digging it from the ground by peeling with sharp sand, grating and soaking in fresh water after which it is filtered and the filtrate is dried and is cooked with other ingredients. The marc, said to be bitter, is usually discarded by deep burial as it is considered poisonous to livestock and humans. All parts of the plant are used in folk medicine to treat various diseases. The aim of this work was to analyze quantitatively the phytochemical, elemental, vitamin and proximate composition of the marc of the tubers with a view of assessing its pharmacological and nutritional potentials. The marc was obtained from Jandeikyura Village in Wukari LGA of Taraba State, Nigeria, and was extracted with $80 \%$ methanol for $\mathbf{7 2} \mathbf{~ h r}$ to give a yield of $10.1 \% \mathrm{w} / \mathrm{w}$ and was whitish in colour. Phytochemical analysis showed the presence of reducing sugars, tannins, flavonoids, steroids, glycosides and hydrogen cyanide at $195.65 \pm 0.5$, $3.44 \pm 0.2,1.29 \pm 0.5,0.83 \pm 0.4,1.36 \pm 1.0$ and $0.00985 \pm 0.3(\mathrm{mg} / 100 \mathrm{~g})$, respectively. The elemental analysis showed the presence of potassium, sodium, magnesium, selenium, manganese, vanadium and some heavy metals like lead, aluminium, arsenic and mercury at $36.45 \pm 0.1,44.04$ $\pm 0.1,1.52 \pm 0.2,0.80 \pm 0.9,0.52 \pm 0.7,0.27 \pm 0.7,0.07 \pm 0.6,0.008 \pm 0.05,0.085 \pm 0.6$ and $0.026 \pm$ $0.6(\mathrm{mg} / 100 \mathrm{~g})$, respectively. Vitamin analysis showed the presence of vitamins A, B1, B2, B3, C and $E$ in various amount as $2.26 \pm 0.8 \mu \mathrm{g}, 0.83 \pm 0.8 \mathrm{mg} / 100 \mathrm{~g}, 0.58 \pm 0.4 \mathrm{mg} / 100 \mathrm{~g}, 0.33 \pm 0.6 \mathrm{mg} / 100 \mathrm{~g}$, $9.80 \pm 0.4 \mathrm{mg} / 100 \mathrm{~g}$ and $6.86 \pm 0.9 \mathrm{mg} / 100 \mathrm{~g}$, respectively. The proximate analysis showed the marc to contain moisture, ash, fats, fibre, crude protein and carbohydrate in the range of $10.83 \% \pm$ $0.3 \%, 1.93 \% \pm 0.6 \%, 1.06 \% \pm 0.5 \%, 4.42 \% \pm 0.4 \%, 6.12 \% \pm 0.6 \%$ and $86.07 \% \pm 0.3 \%$, respectively. This shows that despite the presence of hydrogen cyanide and some heavy metals in traces amount which are considered poisonous to livestock and humans, the marc contains some elements, vitamins, phytochemical and nutrients which are pharmacologically and nutritionally important.

\footnotetext{
*Corresponding author.
}

How to cite this paper: Bosha, J.A., Anaga, A.O. and Asuzu, I.U. (2015) Chemical Composition of the Marc of a Wild Tropical Plant Tacca involucrata (Schumach and Thonn, 1827). Food and Nutrition Sciences, 6, 135-140. 
Keywords

Elements, Phytochemicals, Proximate, Tacca involucrata, Vitamins

\section{Introduction}

Disease and hunger are major problems of human and animal life that affect them in diverse ways. The two are interrelated such that hunger can lead to disease and vice versa. This is evident in the fact that there is an increase in dietary diseases among children and women, especially pregnant and lactating women when there is hunger in the community [1]. The increase in population, especially in the developing world, couple with conflicts, unstable agricultural policies and general lack of commitment to the welfare of the populace by various governments, have further compounded the problem of hunger and disease [2]. There may be no end to this twin problem of hunger and disease if concerted effort by all stakeholders is not made in this direction [3]. A lot of efforts are being made towards solving this twin problem especially that of hunger. According to some workers [4], though measures are being taken to boost food production by conventional agriculture, there exist a need to exploit the vast number of unconventional plants resources that exist in the wild. It has been reported that many of such plants have been identified but lack of data on their chemical composition has limited the prospect of their utilization [5]. Proximate analysis of some of the wild plants indicates that they can fill the gap of nutrition for man and animals [6].

In the tropics, the indigenous people do exploit these wild plants as a measure to avoid hunger and malnutrition. Evidence abound that most rural populations (where these edible wild plants exist) depend on them to meet their hunger and nutritional need [7] [8]. Despite the fact that these plants are consumed by the native population, some of them are known to contain some chemical factors that could be toxic to the body and can be a threat to health hence solving one and creating another problem when taken by humans or animals [9]. It is imperative therefore to have an understanding of the nutritional and chemical composition so as to appreciate their toxicity and ultimately encourage their cultivation and consumption.

Tacca involucrata (Schumach and Thonn, 1827) is a flowering plant of the family Dioscoreaceae. It was formerly classified under the family Taccaceae until 2003 [7]. It is also called Batflower or Polynessian arrowroot. It is distributed from West Africa through South East Asia to Northern Australia. It was intentionally brought to tropical pacific island by early human migration [10] [11]. It is a perennial herb with a tuberous underground rhizome (bulb) from which arises two stems, a petiole 60 - $90 \mathrm{~cm}$ long bearing deeply lobed leaf blades consisting of three main segments, and an inflorescent borne on a long stalk $70-100 \mathrm{~cm}$ with small green flowers surrounded by six or more bracts and numerous thread-like puplish inner bractes [11] [12]. The fruit is an ovoid berry, smooth, about $3.5 \mathrm{~cm}$ long and greenish but turns yellowish when it is ripe and is usually being eaten by children [7]. The tubers are hard, $10-12 \mathrm{~cm}$ in diameter, brownish and potato-like and whitish inside [11].

Traditionally, the tubers are consumed in areas where the plant is found. In Nigeria, it is locally processed after digging from the ground by peeling with sharp sand, grating and soaking in fresh water. Thereafter, it is filtered and the filtrate is dried, cooked and served as a stable food among the people of this area.

Its infusion is used to treat hepatitis and sores of guinea worm infections. Roots and flower are used to treat snake bite. The fruits are eaten by children when they are ripe. It is also used for rituals and as an aphrodisiac by traditional rulers. The water from the grating is used as a detergent [7]. Recently it has been discovered that the marc of Tacca has antidiebetic effects [13].

Despite these numerous uses, the marc from the processed tubers is considered very poisonous to both human and animals such that it is usually discarded by deep burial or thrown far way from human settlement where it is assumed that domestic animals will not come in contact with. In the course of processing it is repeatedly washed as a local way of reducing the poison. Based on these facts above, this study was designed to look at the phytochemical, elemental, vitamins and proximate composition of the marc of the tubers that are considered as stable food and used in treating many disease conditions while its marc is treated with so much fear due to it purported poisoning. This is to give us a better understanding of the composition of the plant to enable us carryout further studies on it. 


\section{Materials and Methods}

The plant material and the marc were obtained from Jandeikyura and Tse-Dzor villages in Wukari Local Government Area of Taraba State Nigeria. Some of the tubers were processed locally to get the marc while the remaining material was identified by Mr. Joshua Waya of the Department of Biological Sciences, Benue State University, Makurdi, Nigeria. The tubers were washed in a pool of water rubbing them on sharp sand to remove the outer cover which is very light, thereafter they were grated and water was added to submerge it. A piece of cloth used in filtering water was used to filter it and the filtrate allowed to sediment over night and decanted. The marc was dried in the sun to a constant weight and extracted with $80 \%$ methanol to give a yield of $10.5 \%$ w/w. Phytochemical analysis was carried out as described by [14] [15]. The following phytochemicals were analysed reducing sugars, tannins, alkaloids, saponnins, flavonoids etc. Elemental analysis was carried out by atomic absorption spectrophotometry (AAS) method and vitamins analysis was carried out as described by Association of Official Analytical Chemists (AOAC) [16]. Vitamin A was estimated by colorimetric method. This involved reacting the extract with antimony trichloride that converts the vitamin into a coloured compound whose absorbance was measured and compared against a standard. Vitamin $\mathrm{C}$ was estimated by titrimetric method. The extract was titrated against the dye DPIP (2, 6-dichlorophenolindophenol). Vitamin C reduced this dye from blue to a colourless form. The dye was standardize against a solution of vitamin $\mathrm{C}$ of known concentration, then the extract was titrated and assayed. The B group and vitamin $\mathrm{E}$ were estimated by fluorimetric method. This is the method used in assaying vitamins that fluoresce. Vitamins that do not possess natural fluorescence are converted to fluorescent derivatives and determined. Proximate analysis was by Kjedahl method and as described by [15]. The analysis consists of moisture, ash, fibre, fats/oil, protein and carbohydrate. This was done in line with the AOAC guidelines [16].

\section{Statistical Analysis}

Result was expressed as mean and standard error of mean. One-way analysis of variance (ANOVA) was used to compare means of variables where applicable.

\section{Results}

The phytochemical analysis of the marc of Tacca involucrata revealed the presence of reducing sugars, 195.65 $\mathrm{mg} / 100 \mathrm{~g}$, saponnins, $15.20 \mathrm{mg} / 100 \mathrm{~g}$, starch, $13.32 \mathrm{mg} / 100 \mathrm{~g}$, tannins, $3.44 \mathrm{mg} / 100 \mathrm{~g}$, alkaloids, $1.43 \mathrm{mg} / 100 \mathrm{~g}$, flavonoids, $1.29 \mathrm{mg} / 100 \mathrm{~g}$ and steroids $0.83 \mathrm{mg} / 100 \mathrm{~g}$ etc. in that descending order (Table 1 ).

The elemental analysis of the same marc indicated that it contain some heavy metals like lead $0.07 \mathrm{mg} / 100 \mathrm{~g}$, aluminium, $0.008 \mathrm{mg} / 100 \mathrm{~g}$, arsenic, $0.085 \mathrm{mg} / 100 \mathrm{~g}$, and mercury, $0.026 \mathrm{mg} / 100 \mathrm{~g}$. It also contain some pharmacological important trace elements like selenium, $0.80 \mathrm{mg} / 100 \mathrm{~g}$, manganase, $0.52 \mathrm{mg} / 100 \mathrm{~g}$, zinc, 1.599 $\mathrm{mg} / 100 \mathrm{~g}$ and chromium, $0.063 \mathrm{mg} / 100 \mathrm{~g}$ etc. (Table 2).

The vitamin analysis showed that the marc of Tacca involucrata contain vitamin C $9.8 \mathrm{mg} / 100 \mathrm{~g}$, vitamin E, $6.86 \mathrm{mg} / 100 \mathrm{~g}$, vitamin A $2.26 \mathrm{mg} / 100 \mathrm{~g}$ etc. (Table 3).

The proximate analysis also revealed the presence of carbohydrate $75.64 \%$, moisture, 10.83 , crude protein, $6.12 \%$, fibre, $4.42 \%$ and fats $1.06 \%$ etc. (Table 4 ).

Table 1. Phytochemical analysis.

\begin{tabular}{cc}
\hline Parameter & Amount $(\mathrm{mg} / 100 \mathrm{~g})$ \\
\hline Reducing sugars & $195.65 \pm 0.5$ \\
Tannins & $3.44 \pm 0.2$ \\
Flavonoids & $1.29 \pm 0.5$ \\
Steroids & $0.83 \pm 0.4$ \\
Glycosides & $1.36 \pm 1.0$ \\
Hydrogen cyanide & $0.00985 \pm 0.003$ \\
Alkaloid & $1.4275 \pm 0.4$ \\
Starch (\%) & $13.320 \pm 0.3$ \\
Saponnin & $15.20 \pm 0.05$ \\
\hline
\end{tabular}


Table 2. Elemental analysis.

\begin{tabular}{ccc}
\hline Parameter & Amount (mg/100g) \\
Potassium & $36.45 \pm 0.1$ \\
Sodium & $44.04 \pm 0.1$ \\
Magnesium & $1.52 \pm 0.2$ \\
Selenium & $0.80 \pm 0.09$ \\
Manganese & $0.52 \pm 0.07$ \\
Vanadium & $0.27 \pm 0.07$ \\
Lead & $0.07 \pm 0.06$ \\
Aluminium & $0.008 \pm 0.005$ \\
Arsenic & $0.085 \pm 0.06$ \\
Mercury & $0.026 \pm 0.06$ \\
Iron & $1.375 \pm 0.3$ \\
Zinc & $1.599 \pm 0.5$ \\
Chromium & $0.0627 \pm 0.02$ \\
Phosphorous & $6.669 \pm 0.6$ \\
Copper & $0.698 \pm 0.04$ \\
\hline
\end{tabular}

Table 3. Vitamins analysis.

\begin{tabular}{cc}
\hline Parameter & Amount $(\mathrm{mg} / 100 \mathrm{~g})$ \\
\hline Vitamin A $(\mu \mathrm{g})$ & $2.26 \pm 0.8$ \\
Vitamin B1 & $0.83 \pm 0.02$ \\
Vitamin B2 & $0.58 \pm 0.04$ \\
Vitamin B3 & $0.33 \pm 0.06$ \\
Vitamin C & $9.80 \pm 0.4$ \\
Vitamin E & $6.86 \pm 0.9$ \\
\hline
\end{tabular}

Table 4. Proximate analysis.

\begin{tabular}{ccc}
\hline Parameter & Amount (\%) \\
\hline Moisture & $10.83 \pm 0.3$ \\
Ash & $1.93 \pm 0.3$ \\
Fats & $1.06 \pm 0.05$ \\
Fibre & $4.42 \pm 0.04$ \\
Crude protein & $6.12 \pm 0.06$ \\
\hline
\end{tabular}

Each value was taken in triplicate.

\section{Discussion}

From the result of the study as seen above, the marc of Tacca involucrata contains some important minerals, vitamins and phytochemicals that make it a good source of food for human and animal consumption.

Most of the phytochemicals present in Tacca marc like reducing sugars, flavonoids, tannin, steriods, alkaloid and saponnins have various nutritional, physiological and pharmacological uses in the body of individuals [1] 
[14] [17].

Flavoniods and saponnins are known to be antioxidant. They prevent the damage caused by free radicals to cells. They can mediate in most cases of chronic diseases such as cancer and diabetes. They also slow or even can stop the proliferation of cancer cells. [1] [14] [17]. Saponnins also help in lowering cholesterol levels thereby preventing arteriosclerosis and hypertensions. It is antitumor and antimutagenic [1]. Saponnins also interfere with the metabolism of vitamin $\mathrm{E}$ and causes gastroenteritis manifesting in diarrhoea and dysentery. So with the high level of vitamin $\mathrm{E}$ in the marc this can be a potential source of toxicity.

The presence of hydrogen cyanide in the marc here shows that this can be toxic. Though it can be argued that the cyanide content here is low compared to the report of other workers. Ubwa [1] reported between 43 - 45 $\mathrm{mg} / \mathrm{kg}$ of cyanogenic glycoside in Tacca peels. It is believed that processing normally reduces the toxicity of Tacca [7]. Therefore the process the Tacca marc underwent may be responsible for the low cyanide content in this study.

The elemental analysis showed that the marc contain some elements that have beneficial effect in the body. For example, Iron apart from been needed by blood carrying haemoglobin also help in immune responses [14]. Zinc, vanadium and manganese help in diabetes. While selenium in conjunction with vitamin $\mathrm{E}$ are good sources of antioxidant [17]. The host of other elements has a lot of beneficial effects in the body.

It can also be observed here that the marc of Tacca contain a reasonable amount of vitamins A, C, E which are all antioxidant vitamins these will have a positive effect on the body of humans and animals that consume it. Antioxidant normally scavange the free radicals from reactive oxygen species in the body. Free radicals are incriminated in the pathogenesis of many chronic diseases like cancers, diabetes etc. [17]. Tacca also contain some traces of the B vitamins.

The proximate analysis also showed that it is a good candidate for nutrition with $76 \%$ carbohydrate, $6 \%$ protein, $4 \%$ fibre, $2 \%$ ash and about $1 \%$ fats. These figures are comparable with other workers like Ubwa [1] who found these to be $71 \%, 2 \%, 4 \%$ and $3 \%$ respectively, while Zuku [3] found them to be $88 \%, 2 \%, 0.2 \%$ and $0.1 \%$ respectively. High level of fibre in food help in treating constipation by expanding the inside walls of the colon, absorbing large amount of water resulting in softer and bulkier stool. It also lowers cholesterol levels in the blood and reduces the risk of cancers and other bowel diseases [1].

The marc also contain some heavy metals that can be toxic to the body of humans and animals like lead, arsenic, mercury, aluminium, etc. Some of the heavy metals like lead have been associated with poisoning in humans. A recent case of lead poisoning in Zamfara State, North Western Nigeria due to illegal mining. Though most of the heavy metals here do not exceed the recommended daily allowance by the American Chemical Society. The recommended daily allowance for most of these heavy metals is $0.1 \mathrm{mg} / \mathrm{day}$. It can be observed that none of the heavy metal is up to that quantity per $100 \mathrm{~g}$. From my interaction and experience with the plant I know that it is not possible for an individual to consume up to $100 \mathrm{~g}$ of the processed flower of Tacca involucrata in one day.

\section{Conclusion}

It can therefore be seen that the marc of Tacca involucrata has all the potentials of a good source of food for humans and animals, and it also contains some potential harmful phytochemicals and heavy metals that can be harmful to health and need to be processed well before consumption. Efforts are underway for more studies on the toxicological and pharmacological effects of the marc.

\section{References}

[1] Ubwa, S.T., Anhwange, B.A. and Chia, J.T. (2011) Chemical Analysis of Tacca leontopetaloides Peels. American Journal of Food Technology, 6, 932-938. http://dx.doi.org/10.3923/ajft.2011.932.938

[2] Anhwange, B.A., Ajibola, V.O. and Oniye, S.J. (2004) Chemical Studies of the Seeds of Moringa oleifera (Lam) and Detarium microcarpum (Guill and Sperr). Journal of Biological Sciences, 4, 711-715. http://dx.doi.org/10.3923/jbs.2004.711.715

[3] Zuku, S.G., Aguzue, O.C., Thomas, S.A. and Barminas, J.T. (2009) Studies on the Functional Properties and Nutritive Values Amura Plant Starch (Tacca involucrata) a Wild Topical Plant. African Journal of Food Science, 3, 320-322.

[4] Aberoumand, A. and Deokule, S.S. (2009) Proximate and Mineral Composition of Wild Coco (Eulophia ochreata L.) Tubers in Iran. Asian Journal of Food and Agro-Industry, 2, 203-209. 
[5] Akubugwo, I.E., Obasi, A.N. and Ginika, S.C. (2007) Nutritional Potential of the Leaves and Seeds of Black Nightshade-Solanum nigrum L. Var Virginicum from Afikpo-Nigeria. Pakistan Journal of Nutrition, 6, 323-326. http://dx.doi.org/10.3923/pjn.2007.323.326

[6] Aberoumand, A. (2011) Nutritive Aspects of Two Food Plants: A Preliminary Comparative Study. Electronic Journal of Environmental, Agricultural and Food Chemistry, 10, 2019-2025.

[7] Burkil, H.M. (1994) The Useful Plants of West Tropical Africa. 3rd Edition, Vol. 5, Royal Botanic Gardens, Kew, 182-184.

[8] Ujowundu, C.O., Igwe, C.U., Enemor, V.H.A., Nwaogu, L.A. and Okafor, O.E. (2008) Nutritive and Anti-Nutritive Properties of Boerhavia diffusa and Commelina nudiflora Leaves. Pakistan Journal of Nutrition, 7, 90-92. http://dx.doi.org/10.3923/pjn.2008.90.92

[9] Yisa, J., Egila, J.N. and Darlinton, A.O. (2010) Chemical Composition of Annona senegalensis from Nupe Land, Nigeria. African Journal of Biotechnology, 9, 4106-4109.

[10] Ukpabi, U.J., Ukenye, E. and Olojede, A.O. (2009) Raw-Material Potentials of Nigerian Wild Polynesian Arrowroot (Tacca leontopetaloides) Tubers and Starch. Journal of Food Technology, 7, 135-138.

[11] National Tropical Biological Garden (2011) http://ntbg.org/donate/

[12] Kunle, O.O., Ibrahim, Y.E., Emeje, M.O., Shaba, S. and Kunle, Y. (2003) Extraction, Physicochemical and Compaction Properties of Tacca Starch: A Potential Pharmaceutical Excipient. Starke, 55, 319-325. http://dx.doi.org/10.1002/star.200390067

[13] Bosha, J.A., Gberinder, F.A. and Asuzu, I.U. (2013) Antihhyperglyceanic Effect of Tacca involucrata on Alloxan Induced Diebetic Rats. Ghana Biomedical Convention, Cape Coast, 56.

[14] Trease, E.C. and Evans, W.C. (2009) Pharmacognosy. 16th Edition, W.B. Saunders, Philadelphia, 365-650.

[15] Pearson, D. (1976) Chemical Analysis of Foods. 7th Edition, Churchhill Livingstone, London.

[16] AOAC (1984) Official Method of Analysis. Association of Official Analytical Chemists, Washington DC.

[17] Bruneton, J. (1994) Pharmacognosy, Phytochemistry, Medicinal Plants. 2nd Edition, Lavoisier Publishing, New York, $1-880$. 
Scientific Research Publishing (SCIRP) is one of the largest Open Access journal publishers. It is currently publishing more than 200 open access, online, peer-reviewed journals covering a wide range of academic disciplines. SCIRP serves the worldwide academic communities and contributes to the progress and application of science with its publication.

Other selected journals from SCIRP are listed as below. Submit your manuscript to us via either submit@scirp.org or Online Submission Portal.
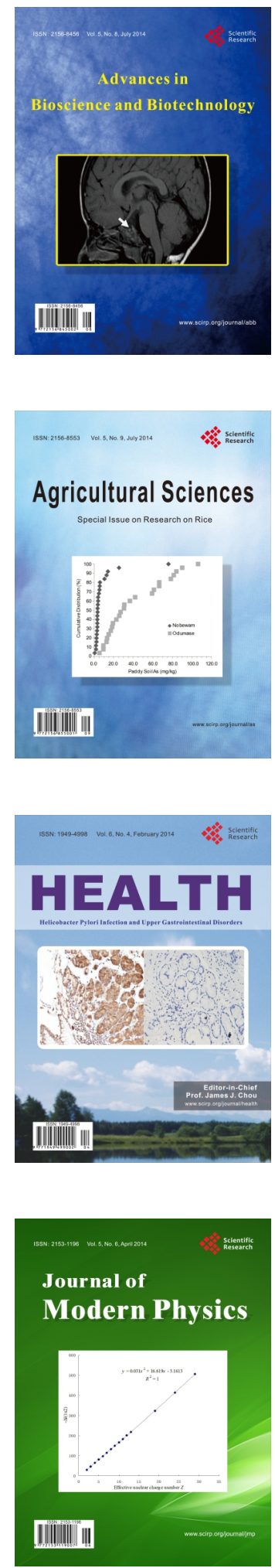
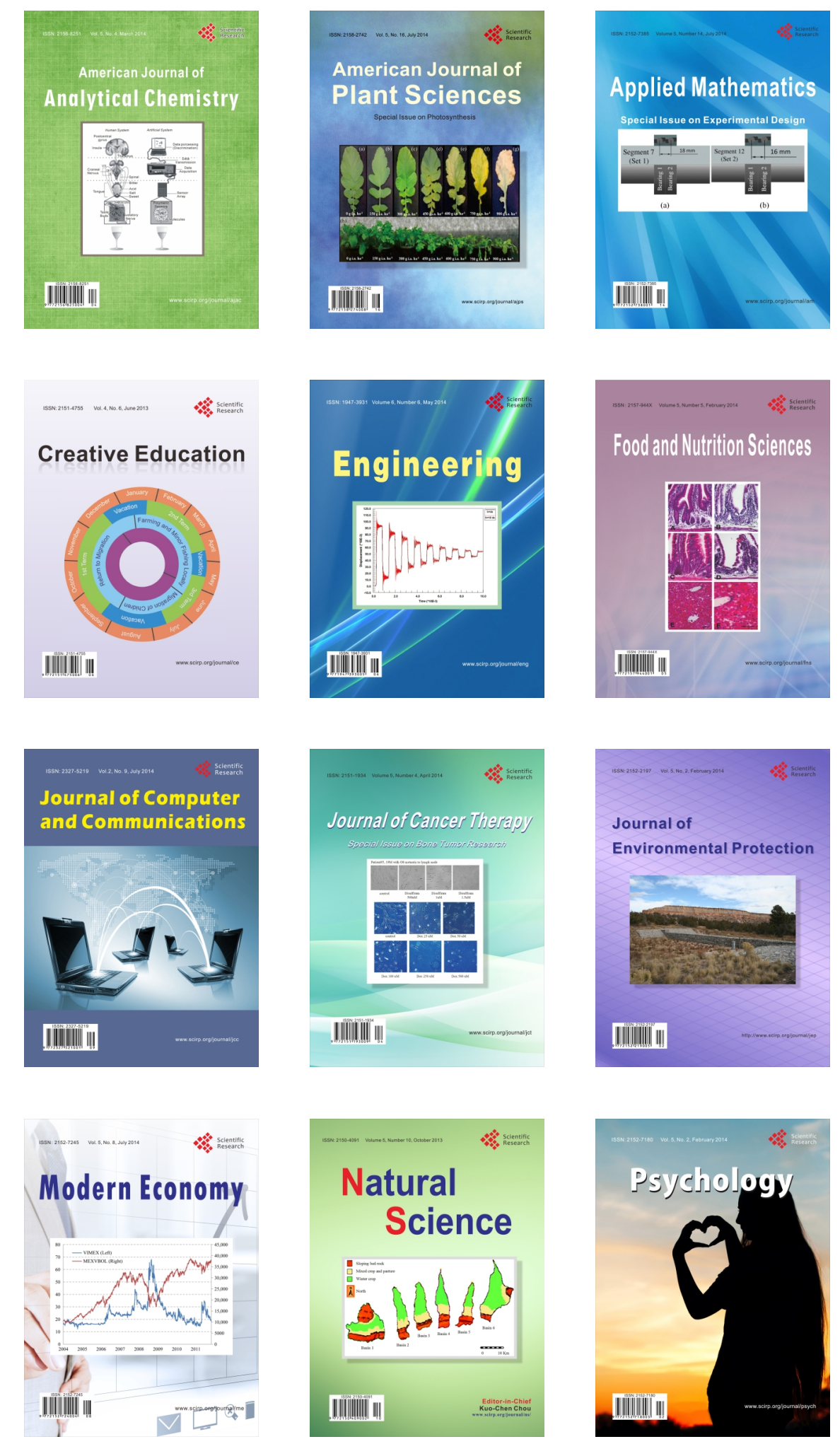